\title{
AKTIVITAS ANTIBAKTERI PENYEBAB VIBRIOSIS TERHADAP UDANG WINDU DARI EKSTRAK HERBAL MANGROVE Sonneratia alba DAN Bruguiera gymnorrhiza
}

\author{
Muliani", Bunga Rante Tampangallo, dan Muharijadi Atmomarsono
}

Balai Penelitian dan Pengembangan Budidaya Air Payau

\begin{abstract}
ABSTRAK
Penelitian ini bertujuan untuk mengetahui aktivitas antibakteri dari ekstrak herbal mangrove Sonneratia alba dan Bruguiera gymnorrhiza terhadap penyebab penyakit vibriosis pada udang windu. Daun mangrove S. alba dan B. gymnorrhiza masing-masing diambil dari Kabupaten Maros dan Pangkep. Sampel daun dikeringanginkan selama dua minggu, ditepungkan, diekstraksi dengan metanol 80\% dan dievaporasi. Rendemen yang diperoleh dipartisi menggunakan dua jenis pelarut yaitu butanol dan dietileter. Uji bioassay dilakukan baik secara kualitatif maupun kuantitatif melalui penentuan minimum inhibition concentration (MIC) dan minimum bactericidal concentration (MBC). Hasil penelitian menunjukkan bahwa aktivitas antibakteri ekstrak mangrove S. alba dan B. gymnorrhiza lebih tinggi terhadap V. parahemolyticus dibanding V. harveyi. Fraksi dietileter dan ekstrak metanol S. alba, serta fraksi butanol B. gymnorrhiza memiliki antibakteri yang tergolong kuat. Ekstrak metanol S. alba bersifat toksik terhadap benur udang windu pada konsentrasi di atas 2.000 $\mathrm{mg} / \mathrm{L}$.
\end{abstract}

KATA KUNCl: antibakteri; herbal mangrove; S. alba; B. gymnorrhiza; udang windu

ABSTRACT: Activity of anti-bacteria cause of vibriosis on tiger shrimp from mangrove herbs Sonneratia alba and Bruguiera gymnorrhiza extract. By: Muliani, Bunga Rante Tampangallo, and Muharijadi Atmomarsono

The experiment was aimed to examine theactivity of anti-bacterial of mangroveherbs Sonneratia alba and Bruguiera gymnorrhiza extract on tiger shrimp. Mangroves leaf of $\mathbf{S}$. alba and B. gymnorrhiza were taken from Maros and Pangkep Regency. Mangrove leaves dried aired approximately two weeks, made into flour, extracted using $80 \%$ metanol, and evaporated. Yield werethen partitioned using two types of solvents are butanol and dietileter. Bioassay test both qualytatively and quantitatively by determination of minimum inhibition concentration (MIC) and minimum bactericidal concentration (M BC). The results showed that the anti-bacterial activity mangrove extract of $\mathbf{S}$. alba and B. gymnorrhiza higher in $\mathbf{V}$. parahemolyticus compared against $\mathbf{V}$. harveyi. Dietileter fraction and the metanol extract of $\mathbf{S}$. alba and buthanol fraction of $\mathbf{B}$. gymnorrhiza have strongly as anti-bacterial. The methanol extract of $\mathbf{S}$. alba will be toxic to black tiger shrimp fry at concentrations above of 2,000 mg/L.

KEYWORDS: $\quad$ anti-bacterial; mngrove herbs; $S$. alba; B. gymnorrhiza; Penaeus monodon

\section{PENDAHULUAN}

Penyakit vibriosis atau penyakit udang berpendar merupakan salah satu jenis penyakit udang yang banyak menimbulkan kematian baik di tambak maupun di panti perbenihan. Vibriosis disebabkan oleh beberapa jenis bakteri vibrio seperti Vibrio harveyi, Vibrio parahaemolytiucus, Vibrio alginolyticus, Vibrio fischeri. Di antara beberapa jenis vibrio yang paling berbahaya adalah V. harveyi (Kannapiran et al., 2009) dan sampai

\footnotetext{
\# Korespondensi: Balai Penelitian dan Pengembangan Budidaya Air Payau. J. Makmur Dg. Sitakka No. 129, Maros 90512, Sulawesi Selatan, Indonesia. Tel. + (0411) 371544 E-mail: mulianim@yahoo.com
}

saat ini penyakit ini masih merupakan kendala budidaya udang terutama di panti perbenihan.

Berbagai upaya telah dilakukan untuk menanggulangi serangan penyakit pada budidaya udang, namun hingga saat ini kematian udang di tambak dan di panti perbenihan akibat serangan penyakit masih saja terus terjadi. Penggunaan bahan alam termasuk mangrove dan tanaman asosiasinya untuk penanggulangan penyakit di bidang perikanan mulai dirintis meskipun masih terbatas pada skala laboratorium di antaranya sebagai antibakteri (Velmurugan \& Citarasu, 2010; Rajasekar et al., 2011; Rajeswari et al., 2012). 
Beberapajenis mangrove telah dilaporkan berperan sebagai antibakteri pada udang seperti R. mucronata dan Salichornia brachiata efektif terhadap Vibrio harveyi, V. vulnificus, V. alginolyticus, V. anginllarum, dan V. lohi. Kedua jenis mangrove tersebut juga efektif terhadap patogen ikan seperti Bacillus subtilis, Serratia sp. Aeromonas hydrophila, V. harveyi, dan V. parahaemolyticus (Manilal et al., 2010; Babuselvam et al., 2012). Selain itu, jenis mangrove ini dapat dijadikan sebagai alternatif pengobatan penyakit vibriosis pada larva lobster (Baskaran \& Mohan, 2012). Sementara, Laith et al. (2011); Laith \& Najiah (2014) melaporkan bahwaE. agallocha efektif terhadap bakteri Flavobacterium spp penyebab penyakit bakterial pada ikan. Selanjutnya Saptiani et al. (2012) melaporkan bahwa fraksi butanol dari daun Acanthus ilicifolius menghambat pertumbuhan $\mathrm{V}$. harveyi lebih baik dibanding ekstrak etilasetat, sedangkan Ramesh et al. (2014) melaporkan bahwa metode ekstrak dengan aceton dari daun $A$. ilicifolius lebih potensial sebagai anti V. harveyi VSH5 dengan diameter hambatan 16,4 $\mathrm{mm}$ dibanding dengan ekstrak daun Avicenia marina, A. ofcinalis, dan Rhizophora mucronata. Laporan Iain menyebutkan bahwa daya hambat etil asetat dari A. ilicifolius terhadap Aeromonas hydrophyla, V. harveyi, dan Escherichia coli berbeda secara signifikan dengan ekstrak etanol dan metanol (Sreenivasa et al., 2015). Ravikumar et al. (2010) melaporkan bahwa metode ekstrak dengan kloroform dari daun Exocaria agllocha mampu menghambat pertumbuhan bakteri patogen pada ikan di antaranya Aeromonas hydrophyla, V. parahaemolyticus, dan V. harveyi.

Selain jenis mangrove yang telah disebutkan, S. alba dan B. gymnorrhiza merupakan jenis mangrove yang juga telah banyak dikaji sebagai antibakteri. Kedua jenis mangrove ini dilaporkan menghambat pertumbuhan bakteri Gram positif yaitu Staphylococcus aureus, Bacillus cereus, B. subtilis, dan Sarcina lutera, dan bakteri Gram negatif penyebab penyakit pada manusia termasuk Escherichia coli, Shigella dysenteriae, Pseudomonas aeruginosa, salmonella typhi, V. parahaemolyticus, dan V. mimicus (Haq et al., 2011; Millon et al., 2012). Muliani et al. (2015) melaporkan bahwa nilai MIC ekstrak metanol S. alba terhadap V. harveyi dan V. parahaemolyticus masing-masing adalah adalah $1 \mathrm{mg} / \mathrm{L}$ dan 0,1 mg/L. Berdasarkan hal tersebut maka dilakukan penelitian yang bertujuan untuk melihat aktivitas antibakteri $V$. harveyi dan V. parahaemolyticus, dari herbal mangrove S. alba dan B. gymnorrhiza pada budidaya udang.

\section{BAHAN DAN METODE}

\section{Pengambilan dan Pengeringan Daun Mangrove}

Daun S. alba dan B. gymnnorrhiza yang digunakan pada penelitian ini masing-masing dikoleksi dari Kabupaten Maros dan Kabupaten Pangkep Provinsi Sulawesi Selatan (Gambar 1). Pengambilan sampel daun dilakukan secara keseluruhan baik daun tua maupun masih muda, selanjutnya dibersihkan dan dikeringanginkan dalam suhu ruang selama kurang lebih dua minggu.

\section{Pembuatan Tepung (Simplisia)}

Daun (daun muda dan daun tua) S. alba dan B. gymnnorrhiza kering, ditepung (simplisia), disaring (ukuran $1 \mathrm{~mm}$ ) dan diekstrak menggunakan pelarut metanol $80 \%$

\section{Ekstraksi Metanol dan Pengkisatan}

Tepung (simplisia) daun mangrove $\mathrm{S}$. alba dan B. gymnnorrhiza sebanyak $5 \mathrm{~g}$, ditambahkan Iarutan metanol 80\%hingga terendam. Cairan hasil penyaringan ditampung sedangkan ampas direndam kembali dengan metanol selama 24 jam dan disaring kembali. Untuk memaksimalkan ekstrak bahan-bahan aktif maka perendaman selama 24 jam dilakukan tiga kali atau tergantung tingkat kekeruhan rendaman. Apabila rendaman sudah terlihat jernih maka perendaman dihentikan. Larutan simplisia hasil ekstraksi disaring ulang menggunakan kertas filter dan dikisatkan dengan menggunakan Rotatory evaporator.

\section{Fraksinasi Hasil Ekstraksi}

Ekstrak S. alba dan B. gymnnorrhiza dilarutkan dengan pelarut dietileter dalam gelas piala dihomogenkan dan dimasukkan ke corong pemisah, diendapkan hingga terbentuk dua lapisan. Masingmasing lapisan dikeluarkan dari corong pemisah. Pelarutan ini diulang 3-4 kali hingga lapisan dietileter terlihat jernih. Sementara, endapan yang tersisa dilarutkan dengan butanol. Proses yang dilakukan sama dengan pemisahan dengan dietileter. Apabila lapisan butanol terlihat jernih, pemisahan dihentikan dan endapan yang tidak larut dalam butanol dikoleksi sebagai fraksi air dan dikisatkan menggunakan freezedryer, sedangkan fraksi dietileter dan butanol dikisatkan menggunakan rotatory evaporator. 


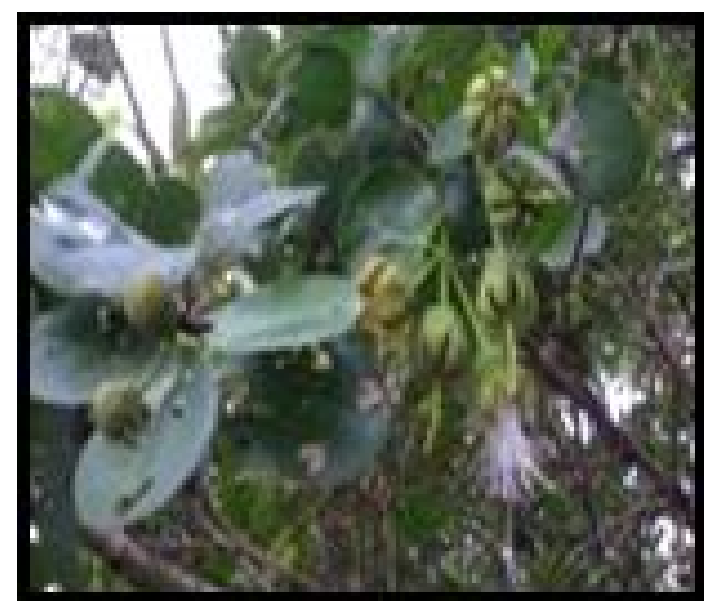

(A) S. alba



(B) B. gymnnorrhiza

Gambar1. Daun mangrove S. alba (A) dan B. gymnnorrhiza (B) yang digunakan untuk uji aktivitas antibakteri dan antiWSSV pada udang windu

Figure 1. Mangrove leaf of S. alba (A) and B. gymnnorrhiza (B) used for anti-bacterial and anti-WSSV activity on black tiger shrimp

\section{Uji Aktivitas Anti-Bakterial Secara Kualitatif}

Uji bioassay untuk melihat aktivitas anti-V. harveyi dan anti-V. parahaemolyticus dari S. alba dan B. gymnnorrhiza dilakukan dengan teknik "High Throughput Screening" (Langfield et al., 2004; Ganju et al., 2008; Karuppusamy \& Rajasekaran, 2009). Hasil fraksinasi dan ekstrak metanol dari kedua jenis mangrove tersebut ditimbang masing-masing sebanyak $5 \mathrm{mg}$ dan $10 \mathrm{mg}$, kemudian dilarutkan dengan $1 \mathrm{~mL}$ DMSO (dimethylsulfoxide) 10\%dalam tabung mikro volume 1,5 mL (Kasanah \& Isnansetyo, 2013). Suspensi isolat V. harveyi (kode 275) dan V. parahaemolyticus (kode isolat-3) masing-masing dikultur dalam media nutrient broth (NB) $10 \mathrm{~mL}$ selama 24 jam pada suhu ruang sambil digoyang. Sebanyak $1 \mathrm{~mL}$ hasil kultur tersebut selanjutnya di subkultur selama empat jam dalam $10 \mathrm{~mL}$ media NB $\left(10^{8} \mathrm{CFU} / \mathrm{mL}\right)$ dan diencerkan hingga diperoleh kepadatan suspensi bakteri V. harveyi dan V. parahaemolyticus sebesar $10^{5} \mathrm{CFU} / \mathrm{mL}$ (Kadriah, 2012).

Suspensi V. harveyi dan V. parahaemolyticus digunakan sebagai bioindikator pada uji bioassay ekstrak mangrove S. alba dan B. gymnorrhiza melalui metode mikrowell plate assay dengan 96 sumuran (Kasanah \& Isnansetyo, 2013). Metode pengujian dilakukan dengan mengisi $40 \mu \mathrm{L}$ media nutrien broth (NB) ke dalam setiap sumur plat mikro, kecuali pada sumur plat mikro untuk kontrol (100 mL). Selanjutnya setiap sumurzn ditambahkan $40 \mu \mathrm{L}$ ekstrak mangrove. Pada sumur plat mikro untuk kontrol media, kontrol pelarut (DMSO), dan kontrol antibiotik tidak dilakukan penambahan ekstrak mangrove. Pada kontrol masing- masing digunakan $40 \mathrm{~mL}$ DMSO 10\%(kontrol pelarut) dan antibiotik rifampisin $40 \mathrm{~mL}$ (kontrol antibiotik). Selanjutnya, suspensi bakteri ditambahkan $20 \mu \mathrm{L}$ ke dalam semua sumur plat mikro kecuali pada kontrol media dan diinkubasi pada suhu ruang selama 24 jam. Pengujian diulang sebanyak tiga kali. Indikator pertumbuhan sel bakteri dengan menambahkan $10 \mu \mathrm{L}$ larutan 3-(4,5-dimethylthiazol-2-yl)-2,5-diphenyltetrazolium bromid (MTT) $5 \mathrm{~g} / \mathrm{L}$ (Wang et al., 2010).

\section{Penentuan Nilai Minimum Inhibition Concentration (MIC)}

M inimum inhibition concentration (MIC) dari ekstrak metanol dan hasil fraksinasi $S$. alba dan B. gymnnorrhiza diujikan terhadap V. harveyi dan V. parahaemolyticus. Uji MIC dilakukan dengan merujuk pada prosedur yang diperkenalkan oleh Kasanah \& Isnansetyo (2013) dengan menggunakan metode mikrowell plate dilution assay.

Ekstrak mangrove hasil faraksinasi yang telah dilarutkan dalam pelarut DMSO $10 \%(5 \mathrm{~g} / \mathrm{mL}$ ) sebanyak $100 \mu \mathrm{L}$ dimasukkan pada sumur plat mikro pertama dan ketujuh, sedangkan pada sumur plat mikro yang lainnya diisi dengan $50 \mu \mathrm{L}$ akuades. Selanjutnya sebanyak $50 \mu \mathrm{L}$ ekstrak mangrove dari sumur plat mikro pertama dan sumur plat mikro ketujuh dipindahkan ke sumur plat mikro berikutnya (sumur plat mikro kedua dan kedelapan), kemudian dihomogenkan dengan pemipetan berulang. Pengenceran dilakukan hingga ke sumur plat mikro keenam dan dua belas. Media NB sebanyak $30 \mu \mathrm{L}$ ke dalam masing-masing sumur plat mikro, baik pada 
kontrol maupun pada sumur plat mikro yang berisi ekstrak mangrove. Suspensi bakteri sebanyak $20 \mu \mathrm{L}$ ditambahkan ke dalam campuran sumur plat mikro kecuali pada kontrol media dan diinkubasi pada suhu ruang selama 24 jam. Penambahan MTT dilakukan setetlah 24 jam masa inkubasi. Perubahan warna media dari kuning menjadi ungu, menunjukkan adanya pertumbuhan sel bakteri (ekstrak mangrove tidak memiliki aktivitas antibakteri), sedangkan jika warna media tetap berwarna kuning (tidak berubah setelah penambahan MTT) tidak ada pertumbuhan sel bakteri. Hal ini mengindikasikan adanya aktivitas antibakteri dari ekstrak mangrove. Konsentrasi ekstrak mangrove terendah di mana tidak terjadi perubahan warna (tidak ada pertumbuhan sel bakteri) merupakan nilai M IC dari ekstrak tersebut (Kasanah \& Isnansetyo, 2013). Data hasil uji bioassay ekstrak mangrove dianalisis secara dekriptif untuk mengetahui nilai MIC dari S. alba dan B. gymnorrhiza.

\section{Penentuan Nilai Minimum Bactericidal Concentration (MBC)}

Penentuan nilai MBC dilakukan setelah pengamatan MIC, yaitu dengan cara biakan dalam plat mikro dikultur pada media TCBSA untuk mengetahui ada tidaknya pertumbuhan bakteri. Biakan diinkubasi selama 24 jam pada suhu $28^{\circ} \mathrm{C}$. Konsentrasi ekstrak mangrove terendah diindikasikan dengan tidak adanya pertumbuhan koloni bakteri (nilai MBC). Data hasil uji nilai MBC dianalisis secara dekriptif.

\section{Uji Tantang Secara In Vitro Metanol S. alba dan B. gymnorrhiza Terhadap V. harveyi}

Ekstrak metanol S. alba dan B. gymnorrhiza diuji tantang dengan $\mathrm{V}$. harveyi pada konsentrasi $1 \mathrm{mg} / \mathrm{L}, 10$ $\mathrm{mg} / \mathrm{L}, 100 \mathrm{mg} / \mathrm{L}, 1.000 \mathrm{mg} / \mathrm{L}$, dan $10.000 \mathrm{mg} / \mathrm{L}$ dengan ulangan masing-masing tiga kali. Uji tantang ekstrak mangrove secara in vitro dengan $\mathrm{V}$. harveyi pada 2.000 $\mathrm{mg} / \mathrm{L}, 4.000 \mathrm{mg} / \mathrm{L}, 6.000 \mathrm{mg} / \mathrm{L}$, dan $8.000 \mathrm{mg} / \mathrm{L}$ dilakukan terhadap S. alba dengan tiga kali ulangan. Ke dalam setiap tabung yang berisi ekstrak mangrove sesuai konsentrasi yang telah ditentukan, dimasukkan biakan bakteri V. harveyi yang berumur empat jam $\left(10^{8} \mathrm{CFU} /\right.$ $\mathrm{mL}$ ) sebanyak $100 \mu \mathrm{L}$ sehingga konsentrasi $\mathrm{V}$. harveyi dalam tabung adalah $10^{6} \mathrm{CFU} / \mathrm{mL}$. Tabung kultur diinkubasi selama 24 jam pada suhu ruang dengan digoyang. Untuk mengetahui pengaruh pemberian ekstrak herbal mangrove, terhadap pertumbuhan V. harveyi maka dilakukan pengamatan populasi V. harveyi menggunakan media TCBS agar.

\section{Uji Toksisitas Ekstrak Metanol S. alba dan} B. gymnorrhiza Terhadap Larva Udang Windu

Uji toksisitas ekstrak metanol S. alba dan B. gymnorrhiza terhadap larva udang windu digunakan konsentrasi yang sama pada uji tantang secara in vitro, $1 \mathrm{mg} / \mathrm{L}, 10 \mathrm{mg} / \mathrm{L}, 100 \mathrm{mg} / \mathrm{L}, 1.000 \mathrm{mg} / \mathrm{L}$, dan 10.000 $\mathrm{mg} / \mathrm{L}$ dengan ulangan masing-masing tiga kali. Uji toksisitas dengan konsentrasi $2.000 \mathrm{mg} / \mathrm{L}, 4.000 \mathrm{mg} /$ $\mathrm{L}, 6.000 \mathrm{mg} / \mathrm{L}$, dan $8.000 \mathrm{mg} / \mathrm{L}$ dilakukan terhadap S. alba. Larva udang yang digunakan adalalh PL-12 yang diambil dari unit perbenihan komersil di Kabupaten Barru, Sulawesi Selatan. Wadah kaca digunakan sebagai wadah uji, diisi air laut $2 \mathrm{~L}$ dengan salinitas $28 \mathrm{ppt}$ dan larva udang windu PL-12 sebanyak 30 ekor. Mortalitas udang windu diamati setelah 96 jam.

\section{HASIL DAN BAHASAN}

\section{Hasil Uji Bioassay Secara Kualitatif}

Hasil uji aktivitas antibakteri secara kualitatif ekstrak metanol (ekstrak kasar) dan hasil fraksinasi dari S. alba dan B. gymnrrhiza terhadap V. harveyi dan $V$. parahaemolyticus menunjukkan bahwa kedua jenis mangrove tersebut positif mengandung anti-V. harveyi dan anti-V. parahemolyticus (Tabel 1).

Tabel 1. Hasil uji bioassay secara kualitatif S. alba dan B. gymnorrhiza terhadap V. harveyi dan V. parahaemolyticus Table 1. Result of qualitative bioassay test of $\mathbf{S}$. alba and $\mathbf{B}$. gymnorrhiza on V. harveyi and $\mathbf{V}$. parahaemolyticus

\begin{tabular}{|c|c|c|c|c|c|c|c|c|}
\hline \multirow{3}{*}{$\begin{array}{l}\text { Jenis } \\
\text { mangrove } \\
\text { Kinds of } \\
\text { mangrove }\end{array}$} & \multicolumn{8}{|c|}{ Aktivitas antibakteri (Anti-bacterial activities) } \\
\hline & \multicolumn{2}{|c|}{$\begin{array}{c}\text { Ekstrak etanol } \\
\text { Metanol extraction }\end{array}$} & \multicolumn{2}{|c|}{$\begin{array}{c}\text { Fraksi air } \\
\text { Water fraction }\end{array}$} & \multicolumn{2}{|c|}{$\begin{array}{c}\text { Fraksi butanol } \\
\text { Buthanol fraction }\end{array}$} & \multicolumn{2}{|c|}{$\begin{array}{l}\text { Fraksi dietileter } \\
\text { Dietileter fraction }\end{array}$} \\
\hline & $\begin{array}{c}\text { V. } \\
\text { harveyi }\end{array}$ & $\begin{array}{c}\text { V. } \\
\text { parahaemolyticus }\end{array}$ & $\begin{array}{c}\text { V. } \\
\text { harveyi }\end{array}$ & $\begin{array}{c}\text { V. } \\
\text { parahaemolyticus }\end{array}$ & $\begin{array}{c}\text { V. } \\
\text { harveyi }\end{array}$ & $\begin{array}{c}\text { V. } \\
\text { parahaemolyticus }\end{array}$ & $\begin{array}{c}\text { V. } \\
\text { harveyi }\end{array}$ & $\begin{array}{c}\text { V. } \\
\text { parahaemolyticus }\end{array}$ \\
\hline S. alba & $\begin{array}{l}\text { Positif } \\
\text { Positive }\end{array}$ & $\begin{array}{l}\text { Positif } \\
\text { Positive }\end{array}$ & $\begin{array}{l}\text { Positif } \\
\text { Positive }\end{array}$ & $\begin{array}{l}\text { Positif } \\
\text { Positive }\end{array}$ & $\begin{array}{l}\text { Positif } \\
\text { Positive }\end{array}$ & $\begin{array}{l}\text { Positif } \\
\text { Positive }\end{array}$ & $\begin{array}{l}\text { Positif } \\
\text { Positive }\end{array}$ & $\begin{array}{l}\text { Positif } \\
\text { Positive }\end{array}$ \\
\hline B. gymnorrhiza & $\begin{array}{l}\text { Positif } \\
\text { Positive }\end{array}$ & $\begin{array}{l}\text { Positif } \\
\text { Positive }\end{array}$ & $\begin{array}{l}\text { Positif } \\
\text { Positive }\end{array}$ & $\begin{array}{l}\text { Positif } \\
\text { Positive }\end{array}$ & $\begin{array}{l}\text { Positif } \\
\text { Positive }\end{array}$ & $\begin{array}{l}\text { Positif } \\
\text { Positive }\end{array}$ & $\begin{array}{l}\text { Positif } \\
\text { Positive }\end{array}$ & $\begin{array}{l}\text { Positif } \\
\text { Positive }\end{array}$ \\
\hline
\end{tabular}




\section{Hasil Uji MIC dan MBC}

Hasil uji MIC dan MBC terhadap hasil fraksinasi dari S. alba dan B. gymnorrhiza disajikan pada Tabel 2. Nilai MIC dan MBC dari semua fraksi terhadap V. harveyi dan V. parahemolyticus dari kedua jenis mangrove tersebut tidak berbeda. Hal ini menunjukkan bahwa kedua jenis mangrove tersebut potensial sebagai penghasil anti-V. harveyi dan anti-V. parahemolyticus. Pada Tabel 2 terlihat pula bahwa nilai MIC dan MBC hasil fraksinasi dari kedua jenis mangrove tersebut terhadap V. harveyi lebih tinggi dibanding nilai MIC dan MBC terhadap V. parahemolyticus. Hal ini mengindikasikan bahwa kedua jenis mangrove lebih efektif terhadap V. parahemolyticus dibanding terhadap V. harveyi. Semakin rendah nilai MIC dan MBC suatu bahan aktif maka efektivitas bahan tersebut semakin tinggi, demikian pula sebaliknya. Hasil uji MIC dan MBC pada Tabel 2 menunjukkan bahwa aktivitas antiV. harveyi dari S. alba tertinggi pada fraksi air dengan nilai $50 \mathrm{mg} / \mathrm{L}$, kemudian fraksi butanol dan selanjutnya fraksi dietileter dengan nilai MIC masing-masing 500 $\mathrm{mg} / \mathrm{L}$ dan $5.000 \mathrm{mg} / \mathrm{L}$. Nilai MIC mangrove ini terhadapi V. parahaemolyticus sama pada setiap fraksi yaitu 0,05 $\mathrm{mg} / \mathrm{L}$. Hasil penelitian sebelumnya menunjukkan bahwa nilai MIC ekstrak metanol S. alba terhadap V. harveyi adalah $1 \mathrm{mg} / \mathrm{L}$ sedang terhadap V. parahaemolyticus adalah 0,1 mg/L (Muliani et al., 2015).

Aktivitas anti V. harveyi dari B. gymnorrhiza tertinggi pada fraksi butanol dengan nilai MIC 50 $\mathrm{mg} / \mathrm{L}$ disusul dengan fraksi dietileter dan fraksi air dengan nilai MIC masing-masing $500 \mathrm{mg} / \mathrm{L}$ dan 5.000 $\mathrm{mg} / \mathrm{L}$. Sementara aktivitas anti V. partahaemolyticus tertinggi pada fraksi butanol dengan nilai MIC 0,05 $\mathrm{mg} / \mathrm{L} ;$ kemudian fraksi dietileter dan selanjutnya fraksi air dengan nilai MIC masing-masing $50 \mathrm{mg} / \mathrm{L}$ dan 500 $\mathrm{mg} / \mathrm{L}$. Muliani et al. (2015) melaporkan bahwa nilai MIC ekstrak metanol B. gymnorrhiza terhadap V. harveyi dan V. parahaemolyticus adalah $0,1 \mathrm{mg} / \mathrm{L}$. Hasil uji MIC dan MBC pada Tabel 2 menunjukkan bahwa fraksi air S. alba potensial sebagai penghasil anti-vibriosis pada budidaya udang windu. Shamsuddin et al. (2013) melaporkan bahwa nilai MIC ekstrak air mangrove $S$. caseolaris terhadap enam jenis bakteri Vibrio sp. penyebab penyakit pada udang adalah $0,1 \mu \mathrm{g} / \mathrm{L}$. Sedangkan Dhayanithi et al. (2013) melaporkan bahwa ekstrak metanol Avicenia marina menunjukkan adanya aktivitas antibakteri terhadap V. angillarum dan V. parahemolyticus masing-masing pada konsentrasi 150 $\mu \mathrm{g} / \mathrm{mL}$ dan $175 \mu \mathrm{g} / \mathrm{mL}$.

Fraksi air dan fraksi butanol S. alba memiliki antiV. harveyi yang tergolong kuat (MIC $50 \mathrm{mg} / \mathrm{L}$ dan 500 $\mathrm{mg} / \mathrm{L}$ ), sedangkan fraksi dietileter tergolong lemah dengan nilai MIC sebesar 5.000 mg/L). Anti-V. harveyi mangrove $B$. gymnorrhiza fraksi butanol dan dietileter tergolong kuat (MIC $50 \mathrm{mg} / \mathrm{L}$ dan $500 \mathrm{mg} / \mathrm{L}$ ), sedangkan fraksi air lemah (MIC $5.000 \mathrm{mg} / \mathrm{L}$ ). Aktivitas anti V. parahaemolyticus dari kedua jenis mangrove ini tergolong kuat pada semua fraksi yang diuji dengan nilai MIC antara 0,05-50 mg/L. Ekstrak metanol dari daun dan batang $\mathrm{S}$. alba memiliki aktivitas anti-V. harveyi yang tergolong kuat dengan diameter masingmasing $24 \pm 3,78$ untuk daun dan $24 \pm 3,78$ untuk batang (Melki et al., 2011). Avenido \& Serrano (2012) melaporkan bahwa ekstrak metanol dari ranting dan daun S. caseolaris memiliki daya hambat terhadap V. harveyi lebih tinggi dibanding ekstrak air. Lebih lanjut dikatakan bahwa ekstrak metanol ranting $S$. alba memiliki aktivitas antibakteri yang lebih kuat dibanding ekstrak daun dengan daya hambat masing $10,33 \pm 1,53$ untuk ranting dan $6,00 \pm 1,73$ ekstrak air pada konsentrasi yang sama yaitu $1.000 \mu \mathrm{g} / \mathrm{mL}$. Abed et al. (2013) menyatakan bahwa bahan antibakteri memiliki daya hambat yang kuat jika nilai MIC-nya adalah $500 \mu \mathrm{g} / \mathrm{mL}$, daya hambat sedang jika nilai MICnya berkisar $600-1.500 \mu \mathrm{g} / \mathrm{mL}$, dan daya hambat rendah jika nilai MIC lebih besar dari $1.600 \mu \mathrm{g} / \mathrm{mL}$.

\section{Hasil Uji Tantang Secara In Vitro dengan V. harveyi}

Hasil uji tantang secara in vitro untuk melihat konsentrasi ambang bawah dan ambang atas yang mematikan V. harveyi disajikan pada Tabel 3. Pada Tabel

Tabel 2. Hasil uji MIC dan MBC hasil fraksinasi S. alba dan B. gymnorrhiza terhadap V. harveyi dan V. parahaemolyticus

Tabel 2. Result of MIC and MBC test of S. alba and B. gymnorrhiza fractinations on V. harveyi and V. parahaemolyticus

\begin{tabular}{|c|c|c|c|c|c|c|}
\hline \multirow{2}{*}{$\begin{array}{l}\text { Jenis } \\
\text { mangrove } \\
\text { Kinds of } \\
\text { mangrove }\end{array}$} & \multicolumn{3}{|c|}{$\begin{array}{l}\text { MIC dan MBC (mg/L) terhadap V. harveyi } \\
\text { MIC and MBC (mg/L) on V. harveyi }\end{array}$} & \multicolumn{3}{|c|}{$\begin{array}{c}\text { MIC dan MBC (mg/L) terhadap V. parahaemolyticus } \\
\text { MIC and MBC (mg/L) on V. parahaemolyticus }\end{array}$} \\
\hline & $\begin{array}{c}\text { Fraksi air } \\
\text { Water fraction }\end{array}$ & $\begin{array}{l}\text { Fraksi butanol } \\
\text { Buthanol fraction }\end{array}$ & $\begin{array}{l}\text { Fraksi dietileter } \\
\text { Dietileter fraction }\end{array}$ & $\begin{array}{c}\text { Fraksi air } \\
\text { Water fraction }\end{array}$ & $\begin{array}{l}\text { Fraksi butanol } \\
\text { Buthanol fraction }\end{array}$ & $\begin{array}{l}\text { Fraksi dietileter } \\
\text { Dietileter fraction }\end{array}$ \\
\hline S. alba & 50 & 500 & 5,000 & 0.05 & 0.05 & 0.05 \\
\hline B. gymnorrhiza & 5,000 & 50 & 500 & 500 & 0.05 & 50 \\
\hline
\end{tabular}


Tabel 3. Populasi V. harveyi (log CFU/mL) setelah 24 uji tantang secara in vitro dengan ekstrak metanol S. alba dan B. gymnorrhiza

Table 3. V. harveyi population ( $\log \mathrm{CFU} / \mathrm{mL}$ ) after 24 hours in vitro challenge with methanol extract of $\mathbf{S}$. alba and B. gymnorrhiza

\begin{tabular}{lcc}
\hline \multirow{2}{*}{$\begin{array}{c}\text { Konsentrasi } \\
\text { Concetrations }\end{array}$} & $\begin{array}{c}\text { Konsentrasi Vibrio sp. (Vibrio sp. Concentration) } \\
\text { (og CFU/mL) }\end{array}$ \\
\cline { 2 - 3 } & S. alba & B. gymnorrihza \\
\hline $1 \mathrm{mg} / \mathrm{L}$ & 7.69 & 7.98 \\
$10 \mathrm{mg} / \mathrm{L}$ & 7.82 & 7.67 \\
$100 \mathrm{mg} / \mathrm{L}$ & 7.86 & 7.81 \\
$1,000 \mathrm{mg} / \mathrm{L}$ & 6.71 & 6.67 \\
$10,000 \mathrm{mg} / \mathrm{L}$ & 0 & 7.98 \\
Kontrol (tanpa ekstrak mangrove) & 8.96 & 8.26 \\
Control (without mangrove extract) & & \\
\hline
\end{tabular}

Sumber (Source): Muliani et al. (2015)

3 terlihat bahwa ekstrak metanol S. alba dengan konsentrasi $10.000 \mathrm{mg} / \mathrm{L}$ mematikan bakteri Vibrio sp. hingga $100 \%$ sedangkan B. gymnorrhiza mematikan Vibrio sp. sekitar 3,4\%dibanding dengan kontrol. Oleh karena itu, uji in vitro ke tahap berikutnya dengan konsentrasi $2.000 \mathrm{mg} / \mathrm{L}, 4.000 \mathrm{mg} / \mathrm{L}, 6.000 \mathrm{mg} / \mathrm{L}$, dan $8.000 \mathrm{mg} / \mathrm{L}$ hanya menggunakan S. alba (Gambar 2).

Pada Gambar 2 terlihat bahwa populasi V. harveyi tertinggi setelah 24 jam kultur terdapat pada kontrol (tanpa ekstrak mangrove), kemudian konsentrasi $2.000 \mathrm{mg} / \mathrm{L}$ dan $4.000 \mathrm{mg} / \mathrm{L}$. Pada Gambar 2 terlihat pula bahwa tidak ada pertumbuhan $V$. harveyi pada konsentrasi $6.000 \mathrm{mg} / \mathrm{L}$ dan $8.000 \mathrm{mg} / \mathrm{L}$. Hasil penelitian sebelumnya menunjukkan bahwa populasi bakteri V. harveyi pada konsentrasi $1,10,100$, dan 1.000 mg/L, masing-masing adalah 6,69; 7,82; 7,86; dan $6,71 \log \mathrm{CFU} / \mathrm{mL}$; sedangkan pada konsentrasi $10.000 \mathrm{mg} / \mathrm{L}$ tidak ada lagi pertumbuhan V. harveyi (Muliani et al., 2015).

\section{Hasil Uji Toksisitas}

Hasil uji toksistas untuk melihat konsentrasi ambang bawah dan ambang atas yang mematikan udang windu disajikan pada Tabel 4. Pada Tabel 4 terlihat bahwa baik ekstrak metanol S. alba maupun ekstrak metanol B. gymnorrhiza dengan konsentrasi 10.000

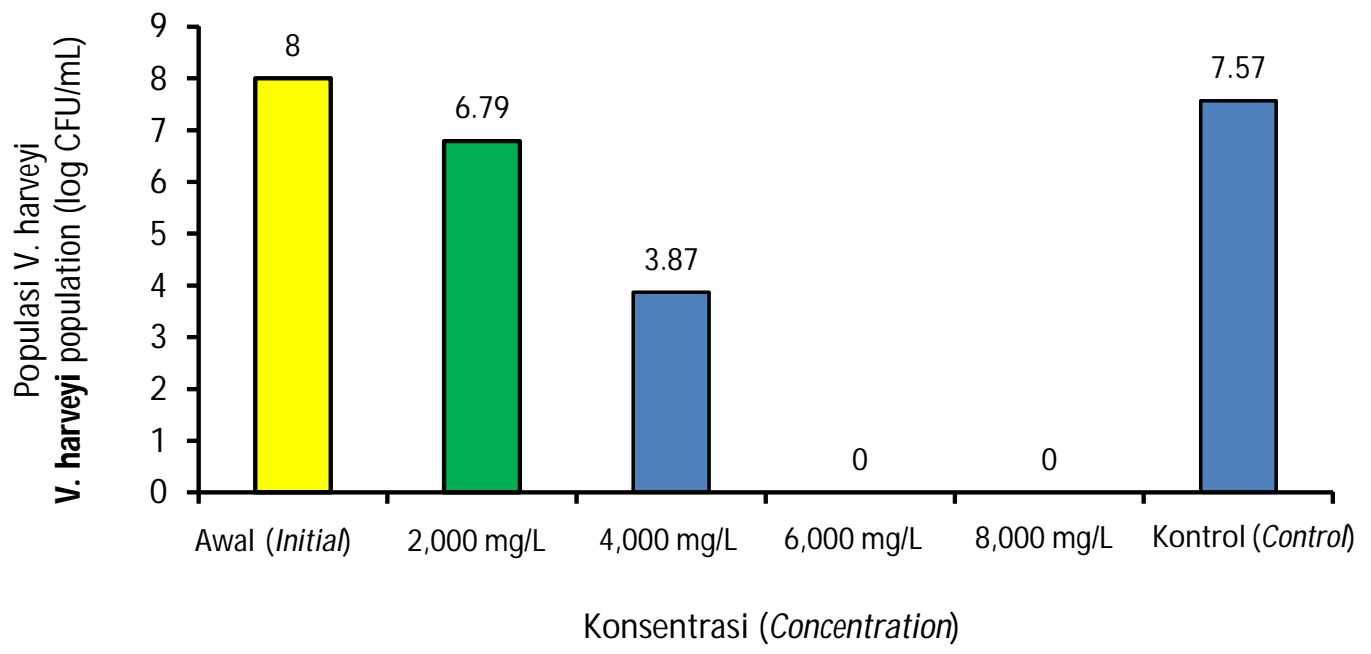

Gambar 2. Populasi V. harveyi (log CFU/mL) setelah 24 jam uji tantang dengan ekstrak metanol S. alba

Figure2. V. harveyi population (log CFU/mL) after 24 hours challenged with methanol extract of S. alba 
Tabel 4. Hasil uji toksisitas ekstrak metanol S. alba dan B. gymnorrhiza terhadap larva udang windu pada konsentrasi yang berbeda

Table 4. Toxicity test result of methanol extracted of $\mathbf{S}$. alba and $\mathbf{B}$. gymnorrhiza on tiger shrimp post larvae at different concentrations

\begin{tabular}{lcc}
\hline \multirow{2}{*}{$\begin{array}{c}\text { Konsentrasi } \\
\text { Concetrations }\end{array}$} & $\begin{array}{c}\text { Mortalitas (\%) larva udang windu setelah 96 jam } \\
\text { Tiger shrimp post larvae mortality (\%) after 96 hours }\end{array}$ \\
\cline { 2 - 3 } & S. alba & B. gymnorrihza \\
\hline $1 \mathrm{mg} / \mathrm{L}$ & 12.22 & 13.33 \\
$10 \mathrm{mg} / \mathrm{L}$ & 12.22 & 5.55 \\
$100 \mathrm{mg} / \mathrm{L}$ & 17.78 & 18.89 \\
$1,000 \mathrm{mg} / \mathrm{L}$ & 31.11 & 95.56 \\
$10,000 \mathrm{mg} / \mathrm{L}$ & 100 & 100 \\
Kontrol (tanpa ekstrak mangrove) & 17.78 & 17.78 \\
Control (without mangrove extract) & & \\
\hline
\end{tabular}

Sumber (Source): Muliani et al. (2015)

Tabel 5. Hasil uji Toksisitas ekstrak metanol daun S. alba terhadap benur udang windu (P. monodon) setelah 96 jam

Table 5. Toxisity test of methanol extract of $\mathbf{S}$. alba leaf on tiger shrimp post larvae (P. monodon) after 96 hours

\begin{tabular}{lc}
\hline \multicolumn{1}{c}{$\begin{array}{c}\text { Perlakuan } \\
\text { Treatments }\end{array}$} & $\begin{array}{c}\text { Tingkat kematian larva udang windu } \\
\text { Mortality of tiger shrimp post larvae (\%) }\end{array}$ \\
\hline $0 \mathrm{mg} / \mathrm{L}$ (kontrol/control) & 36.67 \\
$2,000 \mathrm{mg} / \mathrm{L}$ & 76.67 \\
$4,000 \mathrm{mg} / \mathrm{L}$ & 100 \\
$6,000 \mathrm{mg} / \mathrm{L}$ & 100 \\
$8,000 \mathrm{mg} / \mathrm{L}$ & 100 \\
\hline
\end{tabular}

mg/L mematikan udang 100\% Pada konsentrasi 1.000 $\mathrm{mg} / \mathrm{L}$ ekstrak metanol S. alba mematikan udang windu hingga 31,11\%sedangkan B. gymnorrhiza 95,56\% Oleh karena itu, uji toksisitas ke tahap berikutnya dengan konsentrasi $2.000 \mathrm{mg} / \mathrm{L}, 4.000 \mathrm{mg} / \mathrm{L}, 6.000 \mathrm{mg} / \mathrm{L}$, dan $8.000 \mathrm{mg} / \mathrm{L}$ hanya menggunakan S. alba (Tabel 5).

Pada Tabel 5 terlihat bahwa pada konsentrasi 4.000 $\mathrm{mg} / \mathrm{L}, 6.000 \mathrm{mg} / \mathrm{L}$, dan $8.000 \mathrm{mg} / \mathrm{L}$ ekstrak S. alba sudah bersifat toksik terhadap benur udang windu. Hasil penelitian sebelumnya dilaporkan bahwa mortalitas udang windu pada penggunaan ekstrak metanol S. alba pada konsentrasi $1.000 \mathrm{mg} / \mathrm{L}$ dan $10.000 \mathrm{mg} / \mathrm{L}$ masing-masing sebesar $26,67 \%$ dan $100 \%$ (Muliani et al., 2015). Hal ini menunjukkan bahwa ekstrak metanol dari daun mangrove ini sudah bersifat toksik di atas konsentrasi $1.000 \mathrm{mg} / \mathrm{mL}$. Uji tantang secara in vivo dalam wadah pemeliharaan udang windu menunjukkan bahwa populasi bakteri Vibrio sp. pada pemberian ekstrak metanol S. alba pada konsentrasi $1.000 \mathrm{mg} / \mathrm{L}$ adalah 5,68 x 105 CFU/mL (Muliani et al.,
2016). Laporan lain menyebutkan bahwa populasi bakteri Vibrio sp. dalam air pemeliharaan udang windu setelah 96 jam perendaman dengan ekstrak metanol S. alba $1.000 \mathrm{mg} / \mathrm{L}$ adalah $1,78 \times 10^{3} \mathrm{CFU} / \mathrm{mL}$ (Nurbaya et al., 2016).

\section{KESIMPULAN}

Aktivitas antibakteri ekstrak herbal mangrove S. alba tertinggi pada fraksi air sedangkan B. gymnorrhiza pada fraksi butanol. Antibakteri dari kedua jenis mangrove tersebut tergolong kuat dan memiliki aktivitas anti-V. parahemolyticus lebih tinggi dibanding anti-V. harveyi. Ekstrak metanol S. alba bersifat toksik terhadap benur udang windu pada konsentrasi di atas $2.000 \mathrm{mg} / \mathrm{L}$.

\section{UCAPAN TERIMA KASIH}

Terima kasih kepada rekan-rekan peneliti dan teknisi Laboratorium Kesehatan Ikan dan Lingkungan yang penuh dedikasi dan tanggung jawab membantu 
terlaksananya penelitian ini. Penelitian ini didanai oleh APBN DIPA BPPBAP Maros Tahun 2014.

\section{DAFTAR ACUAN}

Abed, S.A., Sirat, H.M., \& Taher, M. (2013). Total phenolic, antioxidant, antimicrobial activities and toxicity study of Gynotroches axillaris blume (Rhizophoraceae). EXCLI Journal, 12, 404-412.

Avenido, P., \& Serrano, A.E. (2012). Effect of the apple mangrove (Sonneratia caseolaris) on antimicrobial, immunostimulatory, and histological responses in balck tiger shrimp postlarvae fed at varying feeding frequensi. ACCL BIOFLUX, 5(3), 112-123.

Babuselvam, M., Farook, K.A.M., Abideen, S., Mohamed, M.P., \& Uthiraselvam, M. (2012). Screening of antibacterial activity of mangrove plant exract against fish and shrimp patogens. International Journal of Applied Miocrobiology Science, 1(3), 20-25.

Baskaran, R., \& Mohan, P.M. (2012). In vitro antibacterial activity of leaf extracts of Rhizophora mucronata L. against multi drug resisten Vibrio spp. isolated from marine water lobster's larvae hatcheries. Indian Journal of Geo-M arine Science, 41(3), 218-222.

Dhayanithi, N.B., Kumar, T.T.A., Balasubramanian, T., $\&$ Tissera, K. (2013). A study on the effect of using mangrove leaf extracts as a feed additive in the progress of bacterial infections in marine ornamental fish. Journal of Coastal Life M edicine, 1(3), 217-224.

Ganju, K.P.M.L., Sairam, M., Banerjee, P.K., \& Sawhney, R.C. (2008). A review of high throughput technology for the screening of natural products. Biomedicine and Pharmacotherapy, 62(2), 94-98.

Haq, M., Sani, W., Hossain, A.B.M.S., Taha, R.M., \& Monneruzzaman, K.M. (2011). Total phenolic contents, antioxidant and antimocrobial activities of bruguiera gymnorrhiza. Journal of M edicinal Plants Research, 5(17), 4112-4118.

Kadriah, I.A.K. (2012). Pengembangan metode deteksi cepat vibrio berpendar pada udang penaeid. Disertasi. Institut Pertanian Bogor. Bogor, $126 \mathrm{hlm}$.

Kannapiran, E., Ravindran, J., Chandrasekar, R., \& Kalalarasi, A. (2009). Studies on luminous, Vibrio harveyi associated with shrimp culture system rearing Penaeus monodon. J. Environ. Biol., 30(5), 791-795.

Karuppusamy, S., \& Rajsekaran, K.M. (2009). High throughput antibacterial screening of plnat extracts by resazurin redox with special reference to medical plant of western ghats. Global journal of Pharmacology, 3(2), 63-68.
Kasanah, N., \& Isnansetyo, A. (2013). High throughput screening dan bioassay dalam penemuan senyawa bioaktif dari alam. Materi workshop dan Pelatihan Bioprospekting Bahan Alam Kelautan II. Laboratorium Hidrobiologi. Jurusan Perikanan, Fakultas Pertanian, Universitas Gadjah Mada. Jogjakarta, $22 \mathrm{hlm}$.

Laith, A.A., Najiah, M., Zain, S.M., Effendy, S.H.M.A.W., Sifzizul, T.M., Nadirah, M., \& Habsah, M. (2011). In vitro antimicrobial activity of Exoecaria agallocha against Flavobacterium spp. UMTAS, p. 4347.

Laith, A.A., \& Najiah, M. (2014). Antimocrobial activities of blinding tree, Excoecaria agallocha against selected bacterial pathogens. Jounal of Microbiology and Antimocrobial, 6(2), 29-36.

Langfield, R.D., Scarano, F.J., Heitzman, M.E., Konodo, M., Hammond, G.B., \& Neto, C.C. (2004). Use of modified microplate bioassay method to investigate antibcaterial ac tivity in the Peruvian medicinal plant Peperomia galioides. Journal of Ethnophrmacology, 94, 279-281.

Manilal, A., Merdekios, B., tdhayadhulla, A., Muthukumar, C., \& Melkie, M. (2010). An in vitro antagonistic efficacy validation of Rhizophora mucronata. Asian Pac. J. Trop. Dis., 5(1):28-32.

Melki, Soedharma, D., Effendi, H., \& Mustopa, A.Z. (2011). Biopotensi tumbuhan mangrove untuk pencegahan penyakit vibriosis pada udang windu. Maspari Journal, 02, 39-47.

Millon, M.A., Muhit, M.A., Goshwami, D., Masud, M.M., \& Begum, B. (2012). Antioxidant, cytotoxic and antimicrobial activity of Sonneratia alba bark. IJPSR, 3(7), 2233-2237.

Muliani, Nurhidayah, \& Kurniayawan, K. (2015). Herbal mangrove sebagai sumber anti bakteri Vibrio harveyi penyebab penyakit pada udang windu Penaeus mondon. J. Ris. Akuakultur, 10(3), 405-414.

Muliani, Nurhidayah, \& Nurbaya. (2016). Total Vibrio, respons imun, dan sintasan pascalarva udang windu pada penggunaan ekstrak mangrove dengan teknik pemberian berbeda. Makalah telah diseminarkan pada Seminar Nasional Tahunan XIII UGM pada tanggal 13 Agustus 2016. Jogjakarta, $15 \mathrm{hlm}$.

Nurbaya, Susianingsih, E., \& Muliani. (2016). Pengaruh teknik ekstraksi daun mangrove terhadap parameter immun, total vibrio, dan sintasan udang windu pada skala laboratorium. Forum Inovasi Teknologi Akuakultur (FITA) Surbaya, 25-26 April 2016, $9 \mathrm{hlm}$.

Rajasekar, T., Usharani, J., Sakthivel, M., \& Deivasigamani, B. (2011). Immunostimulatory effects of Cardiospermum halicacubum against Vibrio 
parahaemolyticus on tiger shrimp Penaeus monodon. Chem. Pharm. Res., 3(5), 501-513.

Rajeswari, P.R., Velmurugan, S., Babu, M.M., Dhas, S., \& Kesavan, K. (2012). A study on the influence of selected Indian herbal active principles on enhancing the immune system in Fenneropenaeus indicus against Vibrio harveyi infection. Aquaculture International, 20, 1009-1020.

Ramesh, K., Natarajan, M., \& Sridhar, H. (2014). Antivibrio activity of mangrove and mangrove assosiates on shrimp pathogen, Vibrio harveyi VSH5. Global Veterinaria, 12(2), 270-276.

Ravikumar, S., Muthuraja, M., Sivaperumal, P., \& Gnanadesigan, M. (2010). Antibacterial activity of the mangrove leaves Exocaria agalloca against selected fish pathogens. Asian Journal of Medical sciences, 2(5), 211-213.

Saptiani, G., Prayitno, S.B., \& Anggoro, S. (2012). The effectiveness of Acanthus ilicifolius in protecting tiger prawn (Penaeus monodon F.) from Vibrio harveyi infection. Journal of Coastal Develpopment, 15(2), 217-224.
Shamsuddin, A.A., Najiah, M., Suvik, A., Azariyah, M.N., Kamaruzzaman, B.Y., Effendy, A.W., \& John, B.A. (2013). Antibacterial properties of selected mangrove plants against Vibrio species and its cytotoxicity against Artemia salina. World Applied Sciences Journal, 25(2), 333-340.

Sreenivasa, R.M., Teja, G., Sirisha, I.R., \& Yedukondala, R.P. (2015). Screening of antimicrobial activity of mangrove plant Acanthus ilicifolius on shrimp and fish pathogens. Asian Journal of Plant Science and Research, 5(5), 1-3.

Velmurugan, S., \& Citarasu, T. (2010). Effect of herbal antibacterial extracts on the gut floral changes in Indian white shrimp Fenneropenaeus indicus. Romanian Biotechnological Letters, 15(6), 5709-5717.

Wang, H., Cheng, H., Wang, F., Wei, D., \& Wang, X. (2010). An improved 3-(4,5-dimethylthiazol-2-yl)2,5-diphenyl tetrazolium bromide (MTT) reduction assay for evaluating the viability of Escherichia coli cells. Journal of Microbilogical M ethods, 82 , 330-333 